\title{
Food and Feeding Biology of Commercially Important Freshwater Eel, Mastacembelus armatus (LACEPÈDE, 1800) from the Ganga River, India
}

\author{
Absar Alam $^{1 *}$, Vaisakh Gopinath ${ }^{1}$, Dharma Nath Jha ${ }^{1}$, Kripal Datt Joshi ${ }^{2}$, Jeetendra Kumar ${ }^{1}$, Shyamal Chandra \\ Sukla Das ${ }^{1}$, Venkatesh RamaRao Thakur ${ }^{1}$ Monika Gupta ${ }^{1}$ and Basanta Kumar Das ${ }^{1}$
}

${ }^{1}$ ICAR-Central Inland Fisheries Research Institute, India

${ }^{2}$ ICAR-National Bureau of Fish Genetic Resources, India

Submission: December 12, 2019; Published: January 23, 2020

Corresponding author: Absar Alam, Regional Centre, ICAR-Central Inland Fisheries Research Institute, 24-Panna Lal Road, Allahabad, Uttar Pradesh, India

\begin{abstract}
Food and feeding biology of freshwater zig-zag eel Mastacembelus armatus (LACEPÈDE, 1800) was investigated from the Allahabad waters of the river Ganga from April 2015 to March 2016. The Stomach contents of 326 individuals of M. armatus were collected monthly from the Daraganj fish landing centre located on the bank of the river Ganga. The composition of food content was expressed as percentage of the frequency of occurrence $\left(\% \mathrm{O}_{\mathrm{i}}\right)$ and percentage of the volume $\left(\mathrm{V}_{\mathrm{i}}\right)$. The main food items were estimated by Index of preponderance $\left(\mathrm{I}_{\mathrm{i}}\right)$. The three major food items of M. armatus were the small sized teleosts, insects, and molluscs. The analyses of the relative gut length (RGL) revealed it carnivorous type of feeding habit. The Gastro-Somatic Index (GaSI) in the male and female ranged between 2.65 and 4.41 with a mean of $3.42 \pm 0.09$ and 2.84 and 3.43 with a mean value of $3.05 \pm 0.03$. The mean GaSI value differed significantly at $5 \%$ level of significance $(F=6.72, p=0.01)$ in both the male and female indicated significant variation in the feeding habits between both the sexes. This study furnishes baseline information on the food and feeding habits of M. armatus which could be useful in formulation of the management and conservation strategies of this species in the region.

Kewords: Diet composition; Gastro-somatic index; Index of preponderance; Relative gut length; Zig-zag eel
\end{abstract}

\section{Introduction}

M. armatus commonly (Lacepede, 1800), known as zig-zag eel forms an important fishery in the river Ganga [1,2]. It is found to occur in India, Bangladesh, Pakistan, Sri Lanka, Nepal, Burma through Thailand and Malaysia to Southern China [1,3]. It is locally known as Bam or Gend along the stretches of the river Ganga. It is distributed between Haridwar and Hooghly stretch of the River Ganga. It is usually found in wetlands, reservoirs, streams, and rivers with the substrate that is sandy, pebbly or boulder. It is caught mainly by hook and line and gill nets.

M. armatus occurs below the top predators in the food chain and plays a vital role in the freshwater ecosystem as an intermediate predator in maintaining the equilibrium of the structure and ecology of the regional freshwater communities. Overfishing, invasion of exotics, habitat degradation, climate change coupled with pollution have resulted in the population decline of indigenous fish species in the Ganga River [4-10].
Over-exploitation of M. armatus may negatively impact the whole fisheries that can result in a trophic cascade of the immediate trophic levels. M. armatus, the freshwater spiny eel is a major demersal finfish resource inhabiting the inland tropical and subtropical freshwater and brackish water bodies in Asia. Even though it is widely distributed in the Asian continent, there is a little published information on the food and feeding habits of $M$. armatus [11-15].

Examination of the gut content is commonly employed to investigate the composition of food intake and feeding habits $[8,14,15]$. Dietary analysis is widely used in food web ecology and in designing trophic models of fishes for understanding relationships in the aquatic communities in the complex ecosystems [16]. In order to understand the ecological worth of this species, it is crucial to study the food and feeding habits of M. armatus from the different geographical locations around the 
globe. Therefore, the present study was carried out to investigate the diet composition and dietary habits of M. armatus in the River Ganga of north India.

\section{Material and Methods}

A total of 286 samples of $M$. armatus comprising 167 males and 119 females were collected biweekly from the Daraganj fish landing centre located on the bank of the river Ganga at Allahabad (Figure 1), early in the morning for over 12 months. The fish samples collected were immediately kept in an insulated icebox and transported to the laboratory of Allahabad Regional Centre of Central Inland Fisheries Research Institute (CIFRI, Uttar
Pradesh, India). Sexes were noted only after taking total length (TL) and total body weight (W) to the nearest $0.5 \mathrm{~cm}$ and $0.1 \mathrm{~g}$ by dissection in the laboratory. The gut length (nearest $\mathrm{mm}$ ), as well as gut-weight (nearest $0.01 \mathrm{~g}$ ), were recorded separately for males and females, respectively and preserved in $5 \%$ formalin, for subsequent analysis. The prey items in the gut content were identified to the lowest possible taxonomic level employing various identification guides. Stereo-zoom microscope (Nikon SMZ 745T) was used whenever necessary for the identification of the prey items. The gut content of the individual fish was categorised into major groups such as teleosts, insects, crustaceans, molluscs and digested organic matter.

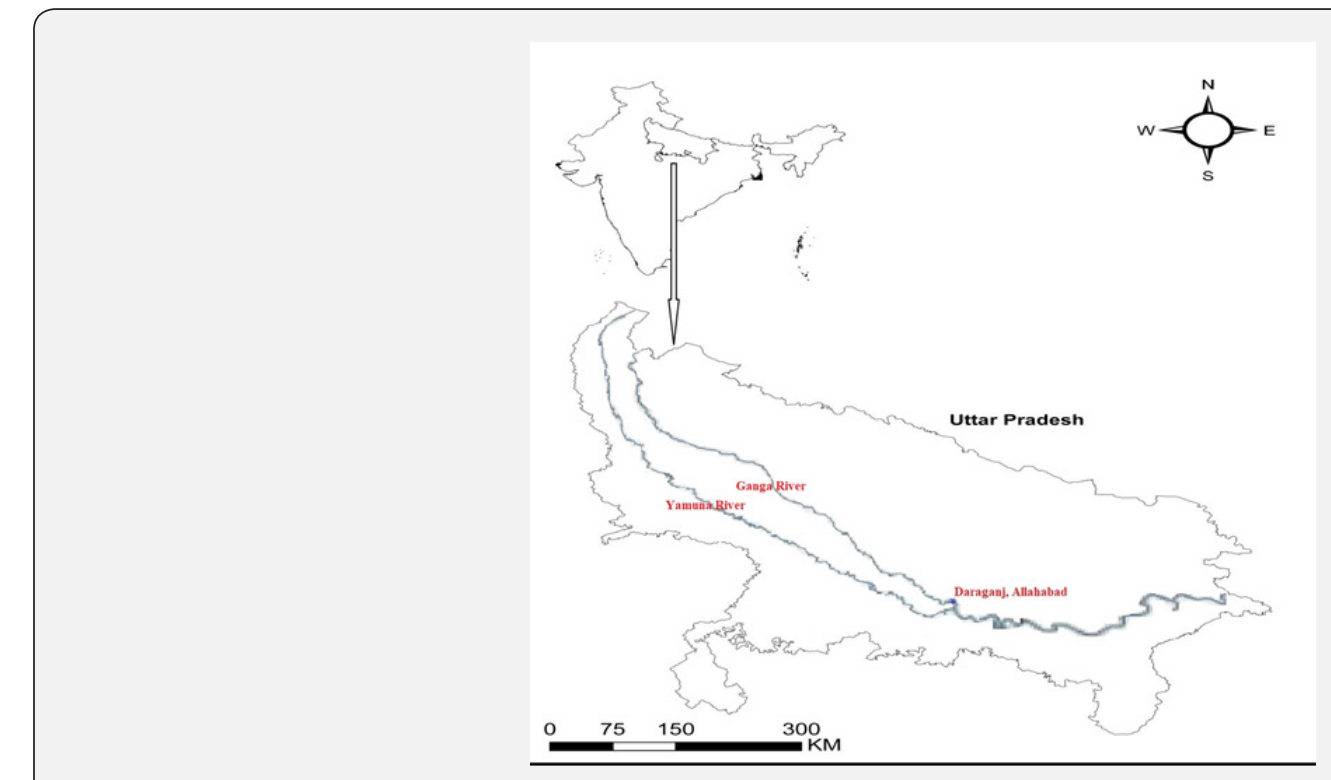

Figure 1: Map showing the sampling center on the bank of the Ganga River at Allahabad.

The percentage occurrence of each major group of items was calculated by multiplying the ratio of the number of times the major group of item occurrence to the total number of guts analysed by a hundred. The percentage volume of each major group of food items was estimated by point method [17]. The Index of preponderance (I) for each food items were computed based on the total occurrence of all food items during the various months and then ranked accordingly [18]. Bodyweight (W) - gutweight $(\mathrm{w})$ and body weight $(\mathrm{W})$ - gut length (L) relationships were established following formula given by Le Cern in1951 [19] as $\mathrm{w}=\mathrm{aW}$ and $\mathrm{L}=\mathrm{aW} \mathrm{W}^{\mathrm{b}}$ where $\mathrm{a}$ and $\mathrm{b}$ are intercepts and regression coefficients of the functional regression between $\mathrm{W}$ and $\mathrm{w} \& \mathrm{~L}$ and $\mathrm{w}$ and after logarithmic transformation has the form of $\log \mathrm{w}=\mathrm{a}+\mathrm{b} \log \mathrm{W}$ and $\log \mathrm{L}=\mathrm{a}+\mathrm{b} \log \mathrm{W}$, respectively The relative length of the gut (RGL) as ratio of total gut length to total length was worked out to analyse its feeding habit. Feeding intensity was estimated based on the Gastro-somatic index (Ga-SI $=$ Weight of the gut $(\mathrm{w}) /$ Body weight $(\mathrm{W}) \times 100)$. The analysis of variance (ANOVA) was done for parameters RGL and GaSI to test their monthly significant differences at a $5 \%$ level of significance employing SAS software (ver.9.3). The multiple comparisons were done using Tukey's test.

\section{Results and Discussion}

Data from 286 individuals of M. armatus containing 167 males and 119 females were examined. The total length (TL) and body weight (W) ranged from 230 to $600 \mathrm{~mm}, 25-373 \mathrm{~g}$ with mean of $409.20 \pm 5.38 \mathrm{~mm}$ and $156.07 \pm 5.26 \mathrm{~g}$ in male while in females it ranged from 230 to $630 \mathrm{~mm}, 29$ to $446 \mathrm{~g}$ with mean of $386.86 \pm$ $5.17 \mathrm{~mm}$ and $142.63 \pm 5.39 \mathrm{~g}$, respectively. The various food items, their percentage composition (by of volume and occurrence) and Pondreal index observed in the gut of M. armatus are depicted in table 1 . Around $39 \%$ of all the guts observed for the gut content analysis were empty and maximum percentage was found between July and October. The small-sized teleosts formed the main food item of the gut content forming $37.37 \%$ volume and 
$30.65 \%$ by occurrence. The major fish genera observed were Barilius, Aspidoparia, Salmophasia, Gudusia, Gonialosa, Chela, Sicamugil, etc. The insects were next principal food item in the diet constituting around $23.04 \%$ and $24.12 \%$ by volume and occurrence, respectively.

Table 1: Volume (\%), occurrence (\%) and Index of preponderance $\left(I_{i}\right)$ observed in the guts $(n=199)$ of $M$. armatus.

\begin{tabular}{|c|c|c|c|c|c|c|}
\hline \multirow{2}{*}{ Sl no } & \multirow{2}{*}{ Food category } & \multicolumn{2}{|c|}{$\%$ composition of food items by } & \multirow{2}{*}{$\mathbf{V}_{\mathrm{i}} \mathbf{O}_{\mathrm{i}}$} & \multirow{2}{*}{$\begin{array}{l}\text { Index of preponderance }\left(\mathrm{I}_{\mathrm{i}}\right) \\
=\left(\mathrm{V}_{\mathrm{i}} \mathrm{O}_{\mathrm{i}} / \Sigma \mathrm{V}_{\mathrm{i}} \mathrm{O}_{\mathrm{i}}\right) \times 100\end{array}$} & \multirow{2}{*}{ Rank } \\
\hline & & occurrence $\left(\mathrm{O}_{\mathrm{i}}\right)$ & Volume $\left(\mathrm{V}_{\mathrm{i}}\right)$ & & & \\
\hline 1 & Teleosts & 30.65 & 37.37 & 1145.58 & 50.41 & I \\
\hline 2 & Insects & 24.12 & 23.04 & 555.83 & 24.46 & II \\
\hline 3 & Molluscs & 17.09 & 17.03 & 290.95 & 12.8 & III \\
\hline 4 & Crustaceans & 8.54 & 6.57 & 56.12 & 2.47 & $\mathrm{~V}$ \\
\hline 5 & Annelids & 5.03 & 0.91 & 4.58 & 0.2 & VI \\
\hline 6 & Digested organic matter & 14.57 & 15.07 & 219.66 & 9.66 & IV \\
\hline Total & & 100 & 100 & 2272.73 & 100 & \\
\hline
\end{tabular}

The dominant genera observed among the insects were the dipteran larvae, the Chironomous followed by the dragonfly nymph. The molluscs mainly small-sized formed the next important food item in the gut comprising $17.03 \%$ by volume and $17.09 \%$ by occurrence. Among the molluscs, the abundant genera were Bellamya and Corbicula and their larvae. The digested organic matter formed the next dominant food item in the diet forming around $15.07 \%$ by volume and $14.57 \%$ by occurrence. The crustaceans constituted by small-sized shrimps and crabs were the next important group of the food item observed in the gut of $M$. armatus forming $6.57 \%$ by volume and $8.54 \%$ by occurrence. Annelids constituted only $0.91 \%$ by volume and $5.03 \%$ by occurrence. The observation of bottom dwellers (smallsized mollusc and shrimps) in the gut content suggested it to be the bottom feeder. Since the major prey organism included nektonic organism (teleosts), it seemed that M. armatus does not feed exclusively on benthic food organisms but also on the prey organism from the water column.
The higher frequency of occurrence and percentage of the volume of teleosts, insects, molluscs and crustaceans in the diet suggested that the feeding habit of the fish was carnivorous. Sand and mud were not recorded in the stomach content agreed with the observations $[12,14]$. The gill rackers are absent in spiny eels [11] which might have influenced the feeding habit as no plant matter was witnessed in the diet of the M. armatus. A wide variety of prey organisms of considerable size ranges recorded in the diet were mostly swallowed in their entire form as it lacks the masticating apparatus [12] to grind the consumed food items, suggested active searching of the environment for its live prey organisms. For the pooled data, RGL value ranged from 0.29 to 0.92 with a mean of $0.64 \pm 0.003$ and varied in different months. The ANOVA test showed that there was a significant difference between both the sexes ( $p=6.32, p=0.0125)$. The mean RGL values also differed significantly in different month in male $(\mathrm{F}=2.89, \mathrm{p}=$ $0.0017)$ and female $(\mathrm{F}=2.13, \mathrm{p}=0.027)$ at $5 \%$ level of significance (Figure 2).

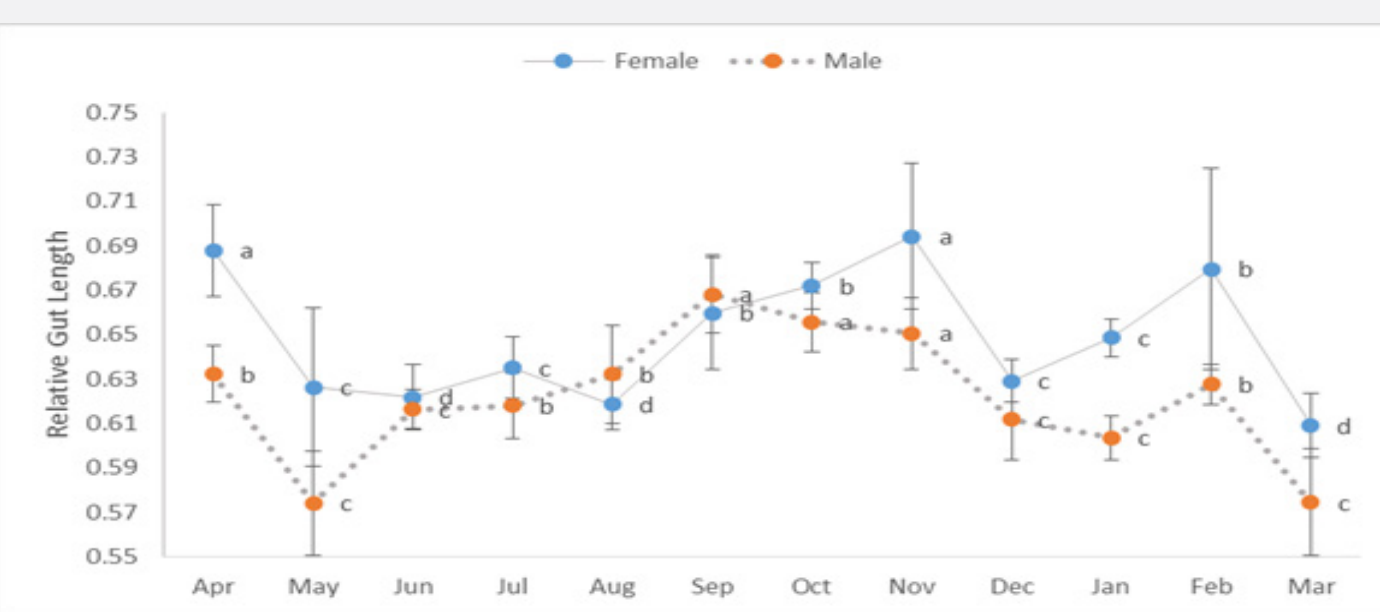

Figure 2: Mean monthly Relative Gut Length $(R G L)$ in male and female of M. armatus from the river Ganga at Allahabad. 
These difference in the feeding might be due to the variations in the available diet in the wild or differences in their sizes and biological factors (maturity stages, GaSI, etc.). Dasgupta in 2004 observed the average RGL value for carnivorous fishes as 0.70 [20]. In the present study, the observed RGL ranged between 0.6 and 0.67 with a mean of $0.64 \pm 0.003$ was in concurrence with the study of Serajuddin and Mustafa [11]. This also indicated that the feeding habit of the fish to be carnivorous, agreed with the earlier studies $[11,12,14]$. The mean monthly Gastro-Somatic
Index (GaSI) in the male and female ranged between 2.65 and 4.41 with a mean of $3.42 \pm 0.09$ and 2.84 and 3.43 with an average value of $3.05 \pm 0.03$ (Figure 3 ). There was a significant difference between the male and female GaSI at $5 \%$ level of significance $(F=6.72, p=0.01)$, suggested that both the sexes did not feed with equal intensity. The monthly mean GaSI was found to be insignificant between the months in the female $(\mathrm{F}=1.84, \mathrm{p}=$ $0.0562)$ while significant in the male $(F=4.23 \mathrm{p}=0.0001)$ at $5 \%$ level of significance [20].

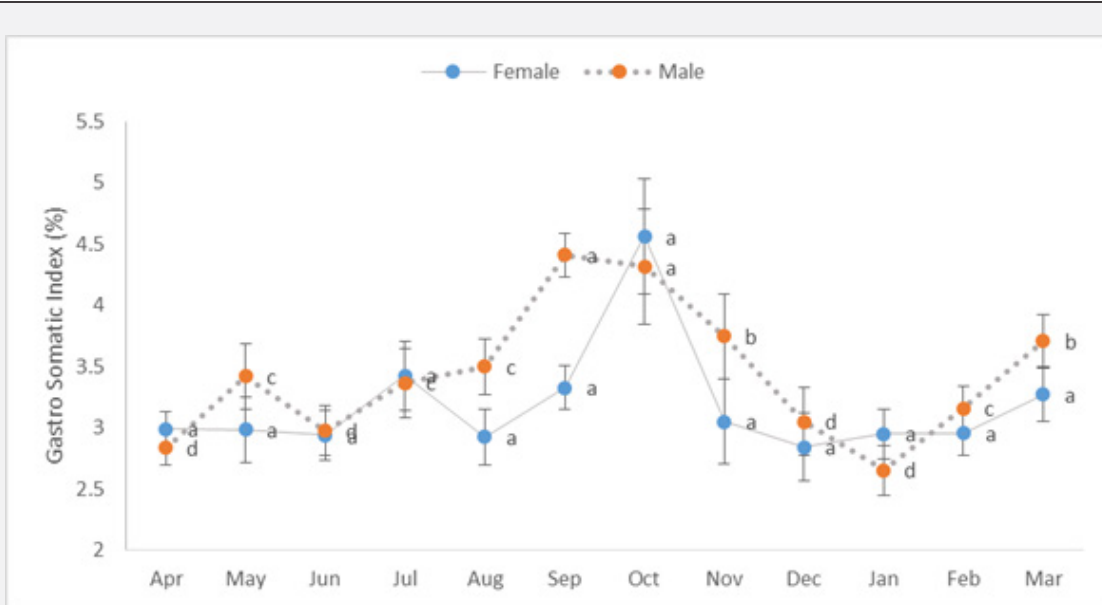

Figure 3: Average monthly Gastro-Somatic Index (GaSI) in the male and female of M .armatus from the river Ganga at Allahabad.

The analysis of GaSI showed variation between the months in male suggested that feeding intensity oscillated round the year. The male showed significantly higher feeding intensity than female as they spent lesser energy in the reproductive process. The feeding intensity of $M$. armatus was observed to be high as $69 \%$ of total guts examined contained food items which were contrary to the report that high percentage of the empty stomachs were observed in the carnivorous fishes [12,14,21,22]. This indicated that the preferred food items were available in plenty in the habitat. In the month of April, July and October, low GaSI was observed in the female. This low intensity of feeding may be due to the stress during peak spawning months when GSI values were high $[8,15]$. The relationship between the body weight $(W)$ and total gut-weight $(\mathrm{w})$ was calculated using the linear regression as: $\mathrm{W}=1.116163+0.024406 \mathrm{~W}\left(\mathrm{R}^{2}=0.51\right)$. The relationship between body weight $(\mathrm{W})$ and gut length $(\mathrm{L})$ was estimates as $\mathrm{L}=17.78146$ $+0.048847 \mathrm{~W}\left(\mathrm{R}^{2}=0.623748\right)$. Both the relationships were found to be highly significant $(\mathrm{p}<0.05)$ and suggested that gut weight and gut length varied with body weight. This variation was more for gut length than gut-weight as $\mathrm{b}$ for body weight-gut length was more than the body weight and gut-weight relationships.

\section{Conclusion}

The present investigation was undertaken to examine the dietary composition and feeding habits of M. armatus from the river Ganga at Allahabad. It fed on a wide variety of food items which were categorized into six distinctive groups viz. teleosts, insects, molluscs, crustaceans, annelids and digested organic matter of animal origin suggested its carnivorous feeding habit. Teleosts were the most preferred food items followed by insects, small-sized molluscs, crustaceans, etc., respectively. M. armatus, an economically important fish with food as well as ornamental value in inland fisheries has the potential for fish diversification and domestication in Asian countries. It is henceforth suggested that additional investigations on other aspects of the biology of this fish species are needed for its successful aqua farming. In the meantime, in situ experiments on the nutritional requirements of this fish can be conducted from the wild collection of juveniles and fingerlings to evaluate its domestic potential. This investigation provides baseline information on the food and feeding habits of $M$. armatus, which would be useful in the management and conservation of this species in the region.

\section{References}

1. Talwar PK and Jhingran AG (1991) Inland fishes of India and adjacent countries. In: Oxford and IBH Publishing Co Pvt Ltd, New Delhi, India.

2. Montana CG, Choudhary SK and Dey S (2011) Composition trends of fisheries in the river Ganga, India. Fisheries Management and Ecology 18 (4): 282-296.

3. Vidthayanon C (2002) Peat swamp fishes of Thailand. In: Office of Environmental Policy and Planning, Bangkok, Thailand.

4. Natarajan AV (1989) Environmental impact of Ganga basin development on gene-pool and fisheries of the Ganga River System. In: Dodge D P (ed.), Proceedings of International Large River Symposium, Canadian Special Publication Fisheries and Aquatic Science 106: 545560 . 
5. Vass KK, Das MK, Srivastava PK, Dey S (2009) Assessing the impact of climate change on inland fisheries in river Ganges and its plains in India. Aquatic Ecosystem Health and Management 12(2): 138-151.

6. Sarkar UK, Pathak AK, Sinha RK, Sivakumar K, Pandian AK, et al. (2012) Freshwater fish biodiversity in the River Ganga (India): changing pattern, threats and conservation perspectives. Reviews in Fish Biology and Fisheries 22: 251-72.

7. Joshi KD, Jha DN, Alam A, Das SCS, Srivastava SK, et al. (2014) Massive Invasion of resilient exotic fishes in the river Ganga: A case study at Allahabad Stretch. Journal of Inland Fisheries Society of India 46(1): 92-95.

8. Alam A, Chadha NK, Joshi KD, Chakraborty SK, Sawant PB, et al. (2015) Food and Feeding Ecology of the Non-native Nile Tilapia Oreochromis niloticus (Linnaeus, 1758) in the River Yamuna, India. Proceedings of the National Academy of Sciences India Section B Biological Sciences 85(1): 167-174.

9. Jha DN, Joshi KD and Tyagi RK (2017) Declined commercial catch of Gangetic Indian major carps at Allahabad. Journal of Inland Fisheries Society of India 49(1): 11-14.

10. Tripathi S, Gopesh A and Dwivedi AC (2017) Fish and fisheries in the Ganga River: Current assessment of the fish community, threats and restoration. Journal of Experimental Zoology India 20 (2): 907-912.

11. Serajuddin M and Mustafa S (1994) Feeding specialization in adult spiny eel, Mastacembelus armatus. Asian Fisheries Sciences 7: 63-65.

12. Serajuddin M, Khan AA and Mustafa S (1998) Food and feeding habits of the spiny eel, Mastacembelus armatus. Asian Fisheries Sciences 11: 271-278.

13. Alam MM, Flowra FA, Hussain MA (2013) Diet composition and feeding intensity of wild zigzag eel, Mastacembelus armatus. Trends in Fisheries Research 2: 24-26.
14. Panikkar P, Khan MF, Sharma AP, Jha BC and Vijaykumar ME (2013) Index of the relative importance of diet components in Mastacembelus armatus (Lacepede, 1800) from Karaphuza reservoir, Waynad, Kerala, India. Indian Journal of Fisheries 60: 37-40.

15. Alam A, Das SCS and Joshi KD (2016) Feeding and reproductive behaviour of the river catfish Rita rita (Hamilton, 1822) in the river Ganga, India. Indian Journal of Animal Sciences 86(6): 736-740.

16. Woodward G and Hildrew AG (2002) Food web structure in riverine landscapes. Freshwater Biology 47: 777-798.

17. Pillay TVR (1952) A critique of the methods of study of food of fishes. Journal of Zoological Society of India 4: 185-200.

18. Natarajan AV and Jhingran AG (1961) Index of preponderance'-a method of grading the food elements in the stomach analysis of fishes. Indian Journal of Fisheries 8: 54-59.

19. Le Cren ED (1951) The length-weight relationship and seasonal cycle in gonad weight and condition in the perch (Perca fluviatilis). Journal of Animal Ecology 20: 201-219.

20. Dasgupta M (2004) Relative length of the gut of some freshwater fishes of West Bengal in relation to food and feeding habit. Indian Journal of Fisheries 51(3): 381-84.

21. Serajuddin M and Ali R (2005) Food and feeding habits of the striped spiny eel, Marcrognathus panchalus (Hamilton). Indian Journal of Fisheries 52(1): 81-86.

22. Suresh VR, Biswas BK, Vinci GK, Mitra K and Mukherjee A (2006) Biology and fishery of barred spiny eel, Macrognathus pancalus Hamilton. Acta ichthyologica et Piscatoria 36(1): 31-37.
Your next submission with Juniper Publishers will reach you the below assets

- Quality Editorial service

- Swift Peer Review

- Reprints availability

- E-prints Service

- Manuscript Podcast for convenient understanding

- Global attainment for your research

- Manuscript accessibility in different formats

( Pdf, E-pub, Full Text, Audio)

- Unceasing customer service

Track the below URL for one-step submission https://juniperpublishers.com/online-submission.php 